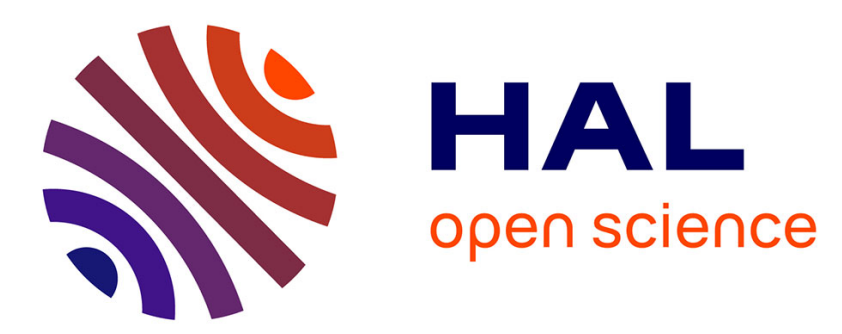

\title{
Fire affects soil organic matter and the emergence of Pinus radiata seedlings
}

\author{
Otilia Reyes, Juan García-Duro, Josefa Salgado
}

\section{To cite this version:}

Otilia Reyes, Juan García-Duro, Josefa Salgado. Fire affects soil organic matter and the emergence of Pinus radiata seedlings. Annals of Forest Science, 2015, 72 (2), pp.267-275. 10.1007/s13595-0140427-8 . hal-01284172

\section{HAL Id: hal-01284172 \\ https://hal.science/hal-01284172}

Submitted on 7 Mar 2016

HAL is a multi-disciplinary open access archive for the deposit and dissemination of scientific research documents, whether they are published or not. The documents may come from teaching and research institutions in France or abroad, or from public or private research centers.
L'archive ouverte pluridisciplinaire HAL, est destinée au dépôt et à la diffusion de documents scientifiques de niveau recherche, publiés ou non, émanant des établissements d'enseignement et de recherche français ou étrangers, des laboratoires publics ou privés. 


\title{
Fire affects soil organic matter and the emergence of Pinus radiata seedlings
}

\author{
Otilia Reyes • Juan García-Duro • Josefa Salgado
}

Received: 17 January 2014 / Accepted: 3 October 2014 / Published online: 30 October 2014

(C) INRA and Springer-Verlag France 2014

\begin{abstract}
- Key message These results present great interest for the knowledge of fire effects and the regeneration capacity of the ecosystems, which is essential to minimise the longterm fire impacts.

- Context This study integrates thermal analysis of soil with tests of fire effects on Pinus radiata seeds germination and field seedling emergence in $P$. radiata plantations. The consequences of fire intensity $P$. radiata plantation regeneration can be predicted from the results.
\end{abstract}

\footnotetext{
Handling Editor: Eric Rigolot

Contribution of the co-authors This work is the first result of a collaboration of researchers of two different departments of the University of Santiago de Compostela with wide experience in the study of different aspects of forest fires: Dr. Reyes, from the Fire Ecology Group of Cellular Biology and Ecology Department, has an extensive curriculum in the germinative and resprouting response of different species after fires and Dr. Salgado, from the Applied Physics Department, is a specialist in the thermal analysis techniques applied to soil study. Thus, the design of the experiments and the work supervision must be attributed to both researchers.

The tasks related with the germinative response and seedling emergence were performed by O. Reyes with the aid of J. García-Duro ( $\mathrm{PhD}$ student) for the sampling and experimental work.

The tasks related with the soil thermal analysis were performed by $\mathrm{J}$. Salgado with the aid of J. García-Duro in soil sampling, handling and laboratory preparation.

The results analysis and manuscript preparation were made by $\mathrm{O}$. Reyes and J. Salgado.
}

O. Reyes $(\square) \cdot J$. García-Duro

Department of Cellular Biology and Ecology, Faculty of Biology,

University of Santiago de Compostela, Campus Vida,

15783 Santiago de Compostela, Spain

e-mail: otilia.reyes@usc.es

J. Salgado

Laboratory of Thermophysical Properties of Fluids and Biomaterials, Department of Applied Physics, University of Santiago de Compostela, EPS, Campus of Lugo, 27002 Lugo, Spain
- Aims This study aims to identify the effects of fire on soil organic matter and emergence of $P$. radiata seedlings in a stand in NW Spain and to test the response of seeds from two provenances of $P$. radiata to smoke and heat.

- Methods Burnt, unburnt and laboratory-heated samples of dry soil were analysed in a differential scanning calorimeter. Based on the comparison between heat released during the combustion of the organic matter of these samples, we estimated the fire severity. Early emergence of $P$. radiata seedlings was recorded in the field after fire. Finally, the effects of fire on seeds germination were tested in the laboratory.

- Results The limited loss of soil organic matter indicated that the fire had been of low severity and that the temperatures reached during the fire remained below the ignition temperatures of soil organic matter. The germination rate was high in controls and the lowest fire severities but decreased with fire intensity. The two provenances differed in their response to fire intensity. Seedling emergence was moderate and varied over time.

- Conclusion The intensity of the investigated fire remained moderate, with a limited loss of soil organic matter. It limited seedling germination and emergence. Nevertheless, despite the scarce seedling emergence observed in the field, reestablishment of the population was possible.

Keywords Emergence $\cdot$ Germination $\cdot$ P. radiata . Provenance $\cdot$ Soil properties $\cdot$ Wildfire

\section{Introduction}

Fire is an ecological and evolutionary factor that has been present in all ecosystems throughout the world for millions of years, perhaps since terrestrial vegetation first existed (Trabaud 1987). Nowadays, forest fires constitute a serious environmental problem, with millions of hectares of forest 
cover throughout the world destroyed every year. In Europe, almost five million of hectares of forest were burned during the decade 1999-2008 (EUROSTAT 2011). As well as destroying ecosystems, forest fires also contribute to climate change.

Soil is a fundamental natural resource in forestry and agriculture. Ecosystem and forest plantation post-fire reestablishment depends on the changes in quality and quantity of soil organic matter (SOM). New, reliable, rapid and nondestructive methods of studying the effects of fire on soil are demanded in the Kyoto Protocol. Since the mid-1990s, Salgado research group has been using calorimetric techniques on SOM to establish reliable bioindicators of soil quality and indicators of the levels of impacts on soils of forest fires (Salgado et al. 1995, 2004).

Pinus radiata does not have the capacity to resprout, and expansion of the populations depends entirely on seed germination. Fire can modify the seed germination response via the physical and chemical cues involved in the germination process. High levels of heat shocks (temperature and/or exposition time) usually reduce the germination percentage of the Pinus species (Reyes and Casal 1995; Escudero et al. 1999; de las Heras et al. 2006). The plant response to the smoke depends on the studied species: positive, negative and neutral effects can be found in literature (Keeley 1994; Keeley and Fotheringham 1998).

Although post-fire regeneration has been studied in different Pinus species (Verkaik and Espelta 2006; Calvo et al. 2008; Vega et al. 2008), the information about post-fire germination of $P$. radiata is scarce (Reyes and Casal 2002a), and no study has considered different provenances of the same species.

Additionally, despite the narrow relation among fire effects on SOM, seed germination and seedling emergence, scanty information about these three approaches in the same study area can be found together. This type of interdisciplinary studies is essential for a clear understanding of the post-fire reproductive strategies of tree species and to enable the design of appropriate management plans.

The main aim of this study is double; firstly, the knowledge of the fire effects on SOM and $P$. radiata seedling emergence in a $P$. radiata stand in NW Spain, and on the other hand, the determination of the heat and smoke effects, in laboratory conditions, of two provenances of $P$. radiata. The specific hypothesis of the study were: (i) fire impact on SOM can be estimated from the soil thermal analysis, (ii) the maximum fire severity will be related with changes on the peak of combustion of SOM after the fire with regard to the corresponding unburnt SOM, (iii) natural germination of two provenances of $P$. radiata will be modified as consequence of the fire (heat and smoke) and (iv) fire will activate the seeds liberation of aereal seed bank and the $P$. radiata seedling emergency will be abundant.

\section{Materials and methods}

\subsection{Study area}

A $P$. radiata plantation in Monte Lúa (Meira, Province of Lugo, NW Spain, $43^{\circ} 09^{\prime} 50^{\prime \prime} \mathrm{N}, 07^{\circ} 14^{\prime} 09^{\prime \prime} \mathrm{W}$ ) was selected for the study. The plantation (6 ha) was established 17 years ago on an area of slope $28^{\circ}$, orientation $45^{\circ} \mathrm{NE}$ and altitude 550 and $630 \mathrm{~m}$. The area was divided vertically into four sectors separated for four horizontal firebreaks and two vertical firebreaks of $4 \mathrm{~m}$ width. The sectors were numbered from I to IV, with sector I corresponding to the topmost sector (Fig. 1). The plantation was burned by a surface forest fire in April 2010, affecting an area of $47 \mathrm{ha}$, corresponding to 40.5 ha of shrubland and 6.5 ha of woodland. Various species of the Ericaceae, Leguminosae and Poaceae families predominated in the understory in the plantation (Table 1). After fire black ashes covered the soil surface, no visual signs of differences of severity could be found among sectors and understory shrubs was partially charred.

\subsection{Soil}

The selected soil was an Entisol with high organic matter content. One week after the fire, four squared of $1 \mathrm{~m}^{2}$ were defined in every sector and four soil samples were collected at random from the top ( $0-2 \mathrm{~cm}$ depth) of the A horizon in every sector. After removal of leaves, branches and plant remains, the soil samples were merged and sieved and the remaining fraction $(<4 \mathrm{~mm})$ was air-dried, ground and homogenised. Unburnt soils located close to the burnt soils in the same area were sampled at the same depth and prepared as above. The unburnt samples were divided in two parts: one part was subjected to heat treatments and considered as heated soil,

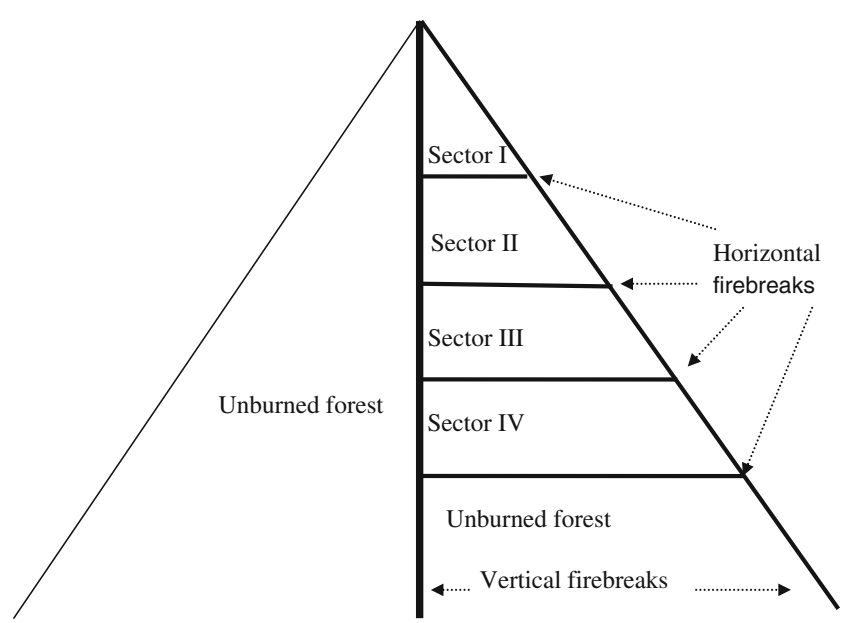

Fig. 1 Scheme of Monte Lúa with indication of sectors and firebreaks. Sectors I, II, III and IV are parts of $P$. radiata populations separated by firebreaks of $6 \mathrm{~m}$ width. The left half and the lowest parts of Monte Lúa were not affected by fire 
Table 1 Inventory of the most abundant Spermatophyta species, with taxonomic family and biological form by Raunkiær (1934) indications, in the $P$. radiata plantation under study

\begin{tabular}{lll}
\hline Species & Family & Biological form \\
\hline Agrostis canina & Poaceae & Hemicryptophyte \\
Agrostis capillaris & Poaceae & Hemicryptophyte \\
Agrostis setacea & Poaceae & Hemicryptophyte \\
Asphodelus sp. & Xanthorrhoeaceae & Cryptophyte \\
Betula pendula & Betulaceae & Phanerophyte \\
Calluna vulgaris & Ericaceae & Chamaephyte \\
Cytisus scoparius & Leguminosae & Chamaephyte \\
Daboecia cantabrica & Ericaceae & Chamaephyte \\
Erica australis & Ericaceae & Chamaephyte \\
Erica ciliaris & Ericaceae & Chamaephyte \\
Erica cinerea & Ericaceae & Chamaephyte \\
Erica umbellata & Ericaceae & Chamaephyte \\
Gentiana neumonanthe & Gentianaceae & Hemicryptophyte \\
Halimium alyssoides & Leguminosae & Chamaephyte \\
Hypochaeris radicata & Asteraceae & Hemicryptophyte \\
Molinia caerulea & Poaceae & Hemicryptophyte \\
Potentilla erecta & Rosaceae & Hemicryptophyte \\
Pinus radiata & Pinaceae & Phanerophyte \\
Pteridium aquilinum & Hypolepydaceae & Criptophyte \\
Quercus robur & Fagaceae & Phanerophyte \\
Salix atrocinera & Salicaceae & Phanerophyte \\
Simethis bicolor & Xanthorrhoeaceae & Cryptophyte \\
Ulex europaeus & Leguminosae & Camaphyte \\
Ulex gallii & Leguminosae & Camaphyte \\
Xolantha globulariifolia & Cistaceae & Hemicryptophyte \\
\hline & & \\
& &
\end{tabular}

and the other part was not heated and was considered as a control, under the assumption that the properties of the unburnt soils were the same as those of the burnt soils before being affected by the fire.

Although the visual signs of the fire presuppose a low severity fire, a deeper study to estimate the maximum temperature reached by the fire was performed. For this propose, samples of unburnt soil, of mass approximately $10 \mathrm{~g}$, were placed on a tray and heated in an oven at $150{ }^{\circ} \mathrm{C}$ for $10 \mathrm{~min}$ and at $200{ }^{\circ} \mathrm{C}$ for 5 or $10 \mathrm{~min}$, which correspond to this severity level (Verdes and Salgado 2011). A comparison between thermal properties of the heated and the burnt soil samples allows to identify the severity of the fire in the forest. Unburnt, laboratory-heated and burnt soil samples were analysed by differential scanning calorimetry (DSC; Q100 TA Instruments). The experiments were performed with samples of approximately $10 \mathrm{mg}$ of soil placed in open aluminium pans under dry air (flow rate, $100 \mathrm{ml} / \mathrm{min}$ ) and at a scanning rate of $10{ }^{\circ} \mathrm{C} / \mathrm{min}$. The temperature interval was $50-600{ }^{\circ} \mathrm{C}$. Samples of indium (mp, $156.6^{\circ} \mathrm{C}$ ) were used to calibrate the DSC. Three replicates per sample were done.
The DSC curves for dried forest soil samples showed two well-defined peaks: a large exothermic peak attributed to combusted SOM and which might represent the overlapping of two peaks corresponding to the thermal degradation of different organic matter compounds (with maximums at $T_{1}$ and $T_{2}$ ), and an endothermic peak, at $575{ }^{\circ} \mathrm{C}$, which can be attributed to structural changes in quartz (Salgado et al. 1995). The heat of combustion ( $Q$; expressed as joules per gramme of sample) was determined by integrating the DSC curves $\left(\mathrm{W} \mathrm{g}^{-1}\right)$ over the exothermic region $\left(150-600{ }^{\circ} \mathrm{C}\right)$. The $Q$ values were divided by the mass loss during each experiment DSC analysis ( $Q$ '; expressed as joules per gramme of organic matter; Rovira et al. 2008). The areas under the DSC curves were divided into three groups representing different degrees of resistance to thermal degradation (Fernández et al. 2011; Pérez-Cruzado et al. 2014): labile organic matter, mainly including carbohydrates and other aliphatic compounds $\left(200-350{ }^{\circ} \mathrm{C}\right)$; recalcitrant organic matter, such as lignin and other polyphenols $\left(350-450{ }^{\circ} \mathrm{C}\right)$; and highly recalcitrant organic matter, such as polycondensed aromatic forms (450$575^{\circ} \mathrm{C}$ ). The resulting partial heats of combustion were designated $Q_{1}, Q_{2}$ and $Q_{3}$, respectively. The following were also determined: temperatures of maximum combustion peaks in the DSC curves $\left(T_{1}\right.$ and $\left.T_{2}\right)$, the temperature at which $50 \%$ of the energy of SOM is released under the given conditions $\left(\mathrm{HT}_{50}\right)$ and the temperature at which the SOM combustion is complete $\left(T_{\text {end }}\right)$. The choice of cut-off temperature varies widely in this type of study, as pointed out in a review paper by Plante et al. (2009). This may be due to the nature of the soil and the differences in experimental conditions, such as sample weight and scanning rate. In this study, we have chosen the most commonly used cut-off temperatures that are consistent with the combustion profile of the samples.

The elemental composition of the samples was determined by the Elemental Analysis Service at the University of Santiago de Compostela.

\subsection{Germinative response}

The germinative response to the effects of fire was determined by using a germination test. Two of the most common provenances of $P$. radiata in plantations of the NW Iberian peninsula were considered: 'Littoral' and 'Inland'. The following fire treatments were tested: control; smoke, $5 \mathrm{~min}$; smoke, $10 \mathrm{~min}$; smoke, $15 \mathrm{~min} ; 80^{\circ} \mathrm{C}, 5 \mathrm{~min} ; 80^{\circ} \mathrm{C}, 10 \mathrm{~min} ; 110^{\circ} \mathrm{C}$, $5 \mathrm{~min} ; 110{ }^{\circ} \mathrm{C}, 10 \mathrm{~min} ; 150{ }^{\circ} \mathrm{C}, 5 \mathrm{~min} ; 150{ }^{\circ} \mathrm{C}, 10 \mathrm{~min}$; $200{ }^{\circ} \mathrm{C}, 5 \mathrm{~min}$; and $200{ }^{\circ} \mathrm{C}, 10 \mathrm{~min}$. Smoke treatments were applied directly with the aid of Fume 2000 smoke applicator, following the methodology described by several authors (Keeley and Fotheringham 1998). The smoke was generated by burning $P$. radiata needles and aerial parts of Ulex europaeus, which are the dominant shrub in the understory. Seeds were placed in Petri dishes in the smoke saturated 
chamber and were maintained under these conditions for 5,10 or $15 \mathrm{~min}$. The temperatures were selected as representative of those registered in the Monte Lúa forest fire (previously determined by study of the impact of the fire on the soil surface) and others of major and minor intensities, as well as temperatures registered at different depths during natural and experimental fires in Atlantic and Mediterranean environments (Díaz-Fierros et al. 1990; Mendes-Lopes et al. 2003) and in other studies (Keeley and Fotheringham 1998; Reyes and Casal 1995; Reyes and Trabaud 2009). A forced-air oven was used to apply the heat shocks. To guarantee the independence of the replicates, each treatment of each provenance was applied separately. To minimise handling, both provenances were treated at the same time. Thus, each group of seeds can be considered a replicate of each provenance. The seeds were incubated in a Phytotron (Climas AGP890) and were maintained for $16 \mathrm{~h}$ under light at $24{ }^{\circ} \mathrm{C}$ and in the dark for $8 \mathrm{~h}$ at $16^{\circ} \mathrm{C}$. Germination was registered as root emergence every Monday, Wednesday and Friday until the end of the experiment (no germination during the last week).

\subsection{Seedling emergence}

To determine the density of emerged seedlings ( $\mathrm{N}^{\circ}$ of seedlings/ $\mathrm{m}^{2}$ ), in each of the four study sectors in Monte Lúa (Fig. 1), the number of alive $P$. radiata seedlings was counted in sampling quadrats of an area of $1 \mathrm{~m}^{2}$, at three different times after fire $(1,3$ and 6 months). In each of the four sectors in which the zone of study was divided, three transects along the slope separated at least $20 \mathrm{~m}$ between them were selected. Sampling quadrats separated $10 \mathrm{~m}$ were placed along these transects. The emerged seedlings density in a total of 153 sampling quadrats was determined during every sampling time.

\subsection{Data analysis}

The seedling density was calculated separately for every sector. Data was transformed with the function log $(1+$ no. of seedlings $/ \mathrm{m}^{2}$ ). The sectors were compared by one-way analysis of variance.

Although the data was transformed, conditions of normality and homocedasticity were not always met. However, the variability analyses were robust and balanced, and therefore these requirements were not taken into account (Underwood 1997).

The average germination percentage and the average time taken for each replicate to reach $50 \%$ of the final germination $\left(\mathrm{GT}_{50}\right.$ rate) were calculated. The germination data for each provenance were analysed by one-way analysis of variance followed by Duncan's test $(p<0.05)$. Data sets were previously checked for normality, and the germination percentage data were subjected to arcsine transformation prior to ANOVA. All data analysis was carried out with PASW Statistics 20 for Windows.

\section{Results}

\subsection{Soil}

The DSC curves for the soils showed two peaks (Fig. 2): the first exothermic peak, between 200 and $550^{\circ} \mathrm{C}$, was attributed to combustion of the SOM and represents the overlapping of two individual peaks, which present the highest rate of degradation at approximately 320 and $380{ }^{\circ} \mathrm{C}$, respectively; a second small endothermic peak, at $575{ }^{\circ} \mathrm{C}$, was related to structural changes in quartz (as it was mentioned in methods section). The area of the exothermic peak in the DSC curves was smaller for the burnt soil than for the unburnt soil. A small shoulder was also observed at approximately $450{ }^{\circ} \mathrm{C}$ in the DSC for the burnt soil but not in the curve for the unburnt soil.

The size of the combustion peak, i.e. the heat released during the combustion of the organic matter of the soils was as follows (Fig. 3):

Unburnt soil $>$ soil heated at $150{ }^{\circ} \mathrm{C}$ for $10 \min >$ burnt soil $>$ soil heated at $200{ }^{\circ} \mathrm{C}$ for $5 \mathrm{~min}>$ soil heated at $200{ }^{\circ} \mathrm{C}$ for $10 \mathrm{~min}$.

Combustion heat of SOM $(Q)$, temperatures of maximum degradation of different organic matter compounds $\left(T_{1}\right.$ and $T_{2}$ ), temperature at which the $50 \%$ of the heat associated with total degradation of organic matter is released $\left(\mathrm{HT}_{50}\right)$ and temperature at the end of the combustion peak $\left(T_{\text {end }}\right)$ are listed in Table 2.

A SOM decrease of $15 \%$ approximately due to the fire were obtained by comparing both the $\mathrm{C}$ content and $Q$ values of unburnt and burnt samples.

The heat of combustion $(Q)$ of the soil heated at $150{ }^{\circ} \mathrm{C}$ for 10 min was not significantly different from that of the unburnt soil, whereas this parameter decreased by almost $40 \%$ in the most severe heat treatment. The opposite tendency was observed in $Q$, i.e. an increase in the value with increasing fire severity.

A shift towards higher values of $T_{1}$ and $\mathrm{HT}_{50}$ was observed on comparing burnt and unburnt soils, although this was not observed in the laboratory-heated samples. Similarly, a small increase in $\% Q_{3}$ accompanied a small reduction in $\% Q_{1}$ was observed in the burnt relative to the unburnt soil, whereas in the heated soils the $\% Q_{1}$ increased, with a consequent decrease in $\% Q_{2}$ and $\% Q_{3}$ with fire severity.

\subsection{Germination}

\subsubsection{Germination percentage}

The germination percentage in controls presents values about $90 \%$ in both provenances of $P$. radiata. Also, germination percentage was very high for smoke and moderate heat treatments (Fig. 4a); However, taking into account all the treatments, highly significant differences were detected between the two $P$. radiata provenances $(p<0.001)$, being the average germination percentage of the 'inland' provenance (44\%) 
Fig. 2 DSC curves for unburnt and burnt soil samples (power per gramme against temperature) between 100 and $600{ }^{\circ} \mathrm{C}$ at $10^{\circ} \mathrm{C} / \mathrm{min}$ under air atmosphere for unburnt and burnt soil samples collected from the surface (0-2 cm deep) of Monte Lúa area. Exothermic down

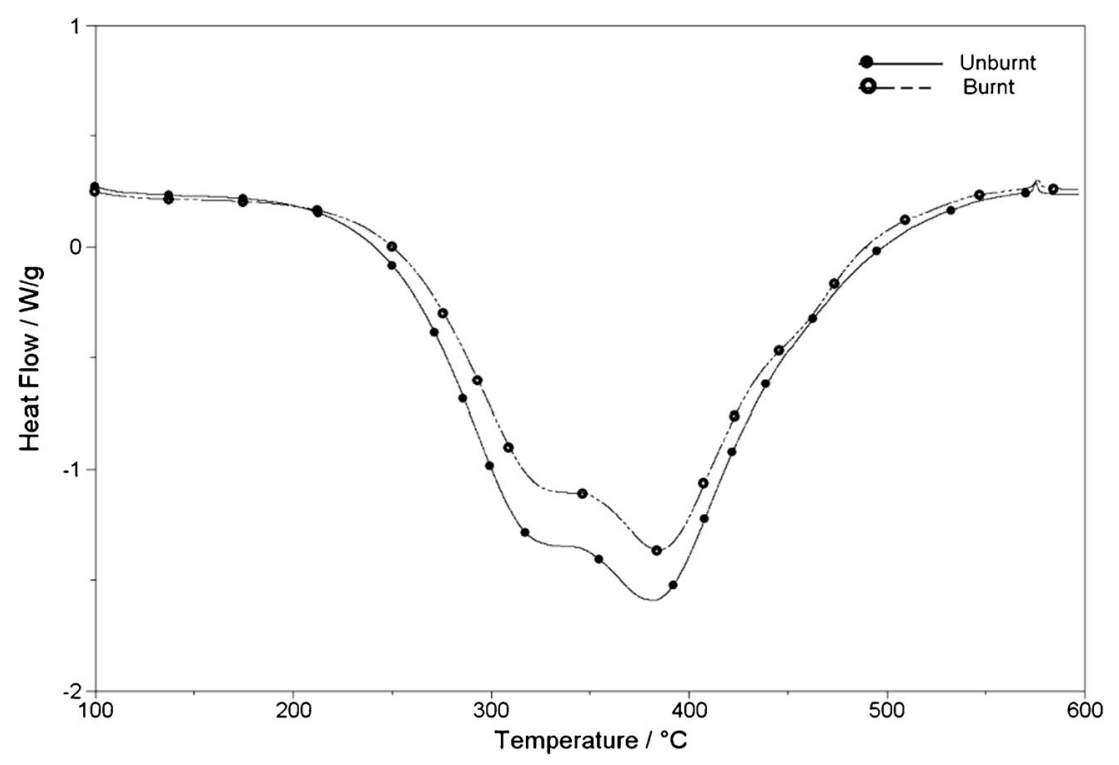

higher than that of the 'littoral' provenance (38\%). Highly significant differences $(p<0.001)$ between treatments were also detected for both provenances. On the contrary, the smoke treatments did not significantly modify the control value (Fig. 4a), in both provenances. Treatments combining high temperature and long-time exposure strongly decreased germination in both provenances. The highest difference between provenances is the heat level necessary for germination process inhibition. Whereas in the littoral the inhibition happens from $80{ }^{\circ} \mathrm{C}$ during $5 \mathrm{~min}$, the inland needs $10 \mathrm{~min}$ at $80^{\circ} \mathrm{C}$ to show the same effect.

\subsection{2 $G T_{50}$ rate}

The control values of the $\mathrm{GT}_{50}$ rate were 13 and 11 days for the littoral and inland provenances, respectively
(Fig. 4b). There were highly significant differences $(p<0.001)$ between both provenances and also within each provenance in relation to the treatments $(p<0.001)$. The average $\mathrm{GT}_{50}$ was 18 days in the littoral provenance, whereas it was only 14 days in the inland provenance. In both provenances, the $\mathrm{GT}_{50}$ rates were generally low in both the control and smoke treatments and increased with heat. In both provenances, heating at $110{ }^{\circ} \mathrm{C}$ for $5 \mathrm{~min}$ and $110{ }^{\circ} \mathrm{C}$ for $10 \mathrm{~min}$ were the only treatments that yielded significant differences from the control.

\subsection{Seedling emergence}

Seedling emergence varied over time (Fig. 5). Thus, 1 month after fire, only one seedling had emerged in the study area. Nevertheless, 3 months after fire, seedlings emergence was on
Fig. 3 Comparison between the DSC curves (power per gramme against temperature) for unburnt, burnt and three heated soil samples between 100 and $600{ }^{\circ} \mathrm{C}$ at $10{ }^{\circ} \mathrm{C} / \mathrm{min}$ under air atmosphere. Exothermic down

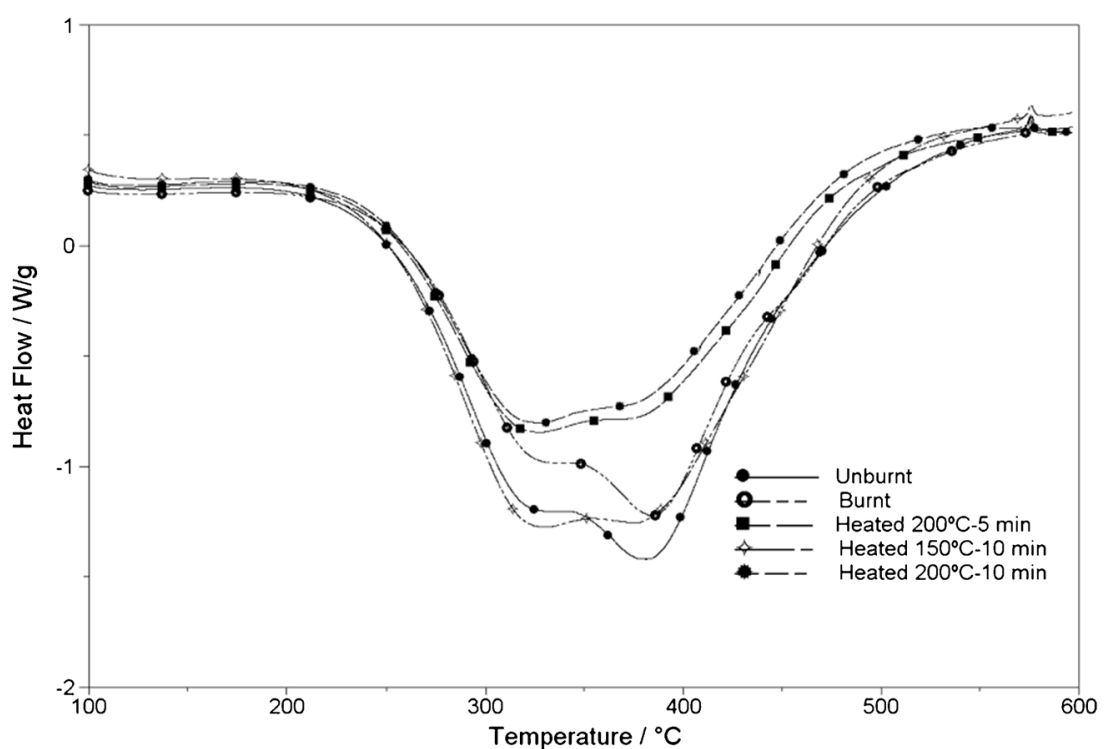


Table 2 Parameters measured in the different soils under study: nitrogen and carbon contains, rate between carbon and nitrogen contains $(\mathrm{C} / \mathrm{N})$, heat released during the combustion per gramme of soil $(Q)$, heat released per gramme of organic matter $\left(Q^{\prime}\right)$, ignition temperature $\left(T_{\text {ign }}\right)$, temperatures of the maximum of the two overlapped SOM combustion peaks $\left(T_{1}\right.$ and $T_{2}$ ), temperature at which the $50 \%$ of the combustion heat is released ( $\left.\mathrm{HT}_{50}\right)$, ending combustion temperature ( $\left.T_{\text {end }}\right)$, partial combustion heats $\left(Q_{i}\right)$ and rate between partial combustion heats and total heat $\left(\% Q_{i}\right)$

\begin{tabular}{|c|c|c|c|c|c|}
\hline & Unburnt & Burnt & $\begin{array}{l}\text { Heated } 150^{\circ} \mathrm{C} \\
(10 \mathrm{~min})\end{array}$ & $\begin{array}{l}\text { Heated } 200^{\circ} \mathrm{C} \\
(5 \text { min })\end{array}$ & $\begin{array}{l}\text { Heated } 200^{\circ} \mathrm{C} \\
(10 \mathrm{~min})\end{array}$ \\
\hline Nitrogen \% & 0.65 & 0.56 & 0.45 & 0.40 & 0.32 \\
\hline Carbon \% & 14 & 13 & 11 & 9 & 7 \\
\hline $\mathrm{C} / \mathrm{N}$ & 22 & 24 & 24 & 22 & 21 \\
\hline$Q(\mathrm{~kJ} / \mathrm{g})$ & 1.7 & 1.5 & 1.78 & 1.2 & 1.2 \\
\hline$Q^{\prime}\left(\mathrm{kJ} / \mathrm{g}_{\mathrm{MO}}\right)$ & 11.9 & 10.7 & 16.0 & 14.1 & 17.7 \\
\hline$T_{\text {ign }}\left({ }^{\circ} \mathrm{C}\right)$ & 246 & 251 & 244 & 243 & 242 \\
\hline$T_{1}$ & 327 & 333 & 330 & 329 & 330 \\
\hline$T_{2}$ & 383 & 382 & 377 & 371 & 374 \\
\hline $\mathrm{HT}_{50}$ & 367 & 370 & 361 & 358 & 355 \\
\hline$T_{\text {end }}$ & 510 & 508 & 500 & 498 & 502 \\
\hline$Q_{1}$ & 706 & 562 & 771 & 564 & 557 \\
\hline$\% Q_{1}$ & 41.2 & 38.8 & 43.9 & 46.0 & 47.0 \\
\hline$Q_{2}$ & 853 & 749 & 843 & 577 & 551 \\
\hline$\% Q_{2}$ & 49.8 & 51.7 & 48.0 & 47.1 & 46.5 \\
\hline$Q_{3}$ & 153 & 139 & 143 & 86 & 76 \\
\hline$\% Q_{3}$ & 8.9 & 9.6 & 8.1 & 7.0 & 6.4 \\
\hline
\end{tabular}

$Q_{1}$ corresponds to heat released between 200 and $350{ }^{\circ} \mathrm{C}, Q_{2}$ between 350 and $450{ }^{\circ} \mathrm{C}$ and $Q_{3}$ between 450 and $575{ }^{\circ} \mathrm{C}$

average 0.78 seedlings $/ \mathrm{m}^{2}$. Finally, 6 months after fire, emergence was on average 0.34 seedlings $/ \mathrm{m}^{2}$, which was equivalent to approximately 20,400 seedlings in the $P$. radiata burnt area, approximately 6 ha. The differences between seedling density recorded on each sampling date were highly significant $(p<0.001)$, and the density on the first sampling date was significantly different from the density on the other two dates. Between-sector differences in seedling density were also significant $(p<0.002)$ specifically between sectors II and III, as sector I was similar to both the other sectors. Sector IV was assumed to be different from the others, as no seedlings emerged, and it was not included in the analysis.

\section{Discussion}

The Monte Lúa wildfire was a surface fire, and the height of the partially carbonised trunks rarely reached $>1.5 \mathrm{~m}$. After the fire, few pine cones were completely opened (personal observation). It was a moderate severity fire according to the classification of Ryan and Noste (1985), which agrees with the small differences in $Q, Q^{\prime}, T_{\text {ing }}, T_{1}$ and $T_{2}$ found between the burnt and unburnt soil. Comparison of the thermal properties of burnt soil and laboratory-heated soil indicated that the impact of the fire on the surface soil (0-2 cm depth) was similar to heating at $150-200{ }^{\circ} \mathrm{C}$. These temperatures are lower than ignition temperature, corresponding, accordingly to the results of Verdes and Salgado (2011) to a low severity fire. Although laboratory-based heating experiments provide helpful information about the effects of high temperatures in soil properties, the data must be considered carefully in relation to forest fires, in which different factors interact in a complex way (Marcos et al. 2007; Verdes and Salgado 2011). This is further illustrated by the differences in the shapes of the DSCs for the laboratory-heated and burnt soil samples. Thus, in burnt soil, the main decrease in SOM corresponded to carbohydrates, aliphatic structures and carboxylic groups, in which thermal degradation occurred between 200 and $350{ }^{\circ} \mathrm{C}$. In contrast, in the laboratory-heated samples, all structures appeared to be affected, even the most resistant ones, in which degradation occurred up to $450{ }^{\circ} \mathrm{C}$ (Dell'Abate et al. 2003; Plante et al. 2009; Rovira et al. 2008; De la Rosa et al. 2008). This is probably because the soil receives contributions from partially burnt plant remains in forest fires, which display a high degree of thermal resistance. This observation is consistent with the shoulder at $470{ }^{\circ} \mathrm{C}$ that appears in the DCS profile of the soil burned. However, this was not observed in the laboratory-heated samples. Nevertheless, the $Q^{\prime}$ increase and the $Q$ decrease against the severity of the laboratory heating indicate that the organic matter remaining after the thermal shock is the fraction that stores most internal energy. 
Fig. 4 Average germination percentage and standard deviation (a) and average $\mathrm{GT}_{50}$ and standard deviation (b) in littoral and inland provenances of $P$. radiata reached with each experimental fire treatments. In each provenance, the treatments that yielded significant differences are indicated by different letters
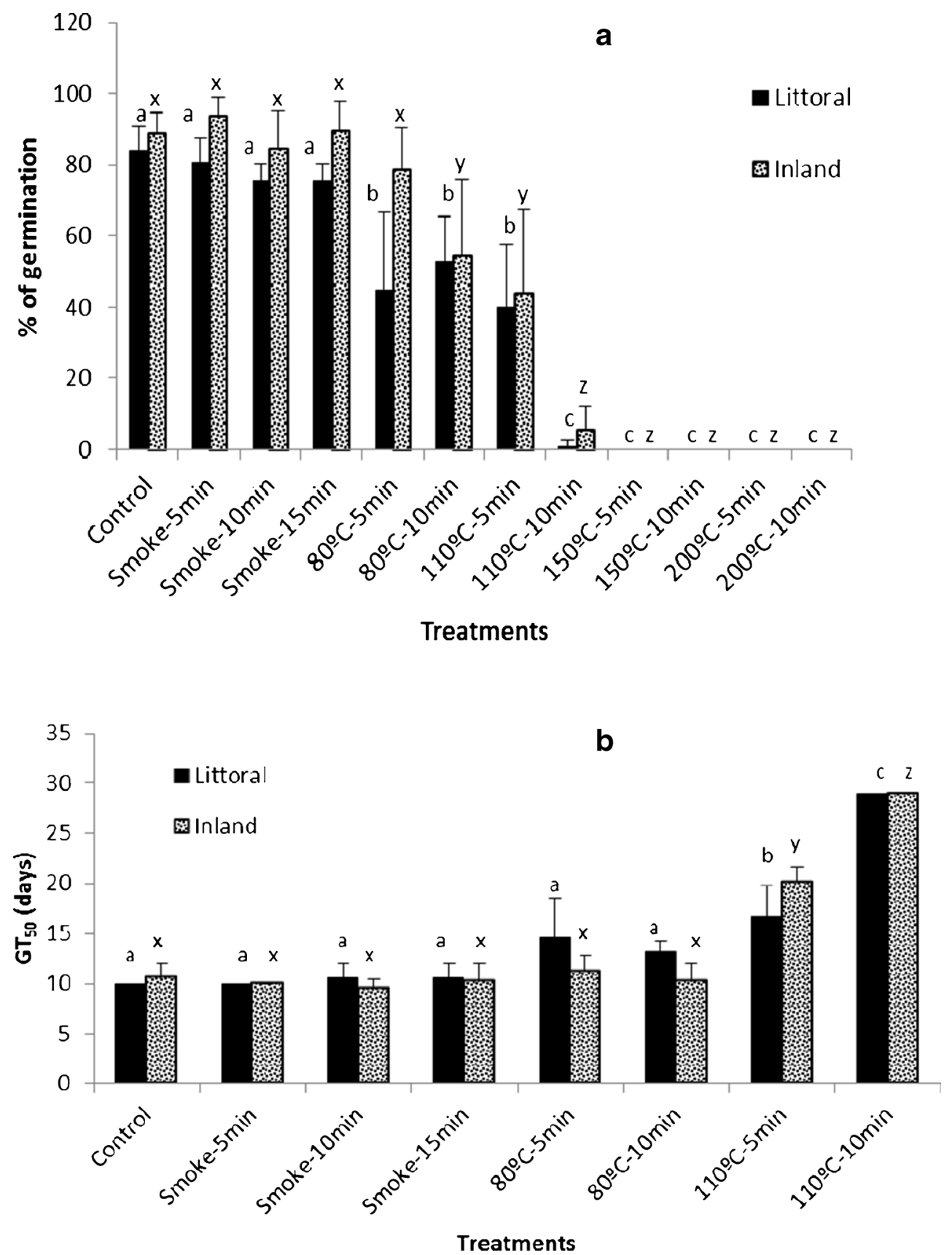

Natural germination can be modified by the temperature reached during fire and the time during which seeds are subjected to high temperature (Reyes and Casal 1995), as well as by inputs of ash (Pausas et al. 2003; Reyes and Casal 1998). Germination of many Pinus species is partially inhibited at temperatures of $90-110{ }^{\circ} \mathrm{C}$, i.e. at fire intensities lower than that corresponding to the Monte Lúa fire (Reyes and Casal 1995; Escudero et al. 1999). In the provenances under study here, germination tended to be reduced with temperatures increasing being completely inhibited in the most severe treatments $\left(>150{ }^{\circ} \mathrm{C}\right)$. The inland provenance is more resilient to fire than the littoral provenance because it supports higher temperatures and germinates in less time, agreeing with Mollashahi and Hosseini (2007) who also found that germination differed in three different provenances of $P$. radiata.

On the other hand, smoke did not have an important effect on the germination percentage or the $\mathrm{GT}_{50}$ rate in the $P$. radiata provenances under study. Studies with 8 of the 11 most abundant pine species in Europe (Pinus halepensis, Pinus canariensis, Pinus pinea, P. radiata, Pinus sylvestris, Pinus nigra, Pinus uncinata, Pinus pinaster) showed similar response to heat and smoke (Reyes and Casal 1995, 2006; Escudero et al. 1999). Low levels of fire agents have a neutral effect on the germination of pine trees, irrespective of 


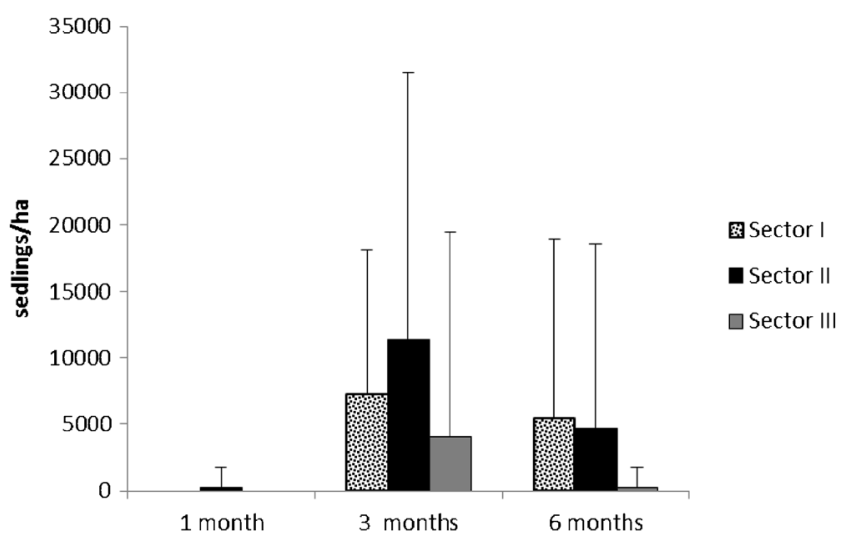

Fig. 5 Mean number (and standard deviation) of all emerged seedlings of $P$. radiata per hectare present in the plantation under study at the different sampling times including the mortality of seedling emerged previously

exposure, intensity or concentration. When the action of the fire agents is intensified by a longer exposure time or by larger doses, it tends to inhibit germination, and the inhibition increases with the intensity of the agent (Reyes and Trabaud 2009).

For the severity level compatible with SOM loss after fire, the germination results show that seeds do not survive such temperatures. Additionally, P. radiata is characterised by having serotinous cones (Keeley 1994; Reyes and Casal 2002b), by the formation of a persistent aerial seed bank (Reyes and Casal 2002b) and by not having a permanent soil seed bank (Moles and Drake 1999). The seeds are usually liberated of the bank several hours after the fire (Reyes and Casal 2002b) reaching the soil surface when the soil temperature does not inhibit seeds germination. Taking into account that the canopy temperature was much lower than soil temperature, the main part of the seed bank could not be liberated after the fire (Reyes and Casal 2002b; Vega et al. 2008) and this explicate the scarce seedling emergence. Three months after the fire, seedling emergence was 0.78 seedlings $/ \mathrm{m}^{2}$, which is lower than reported values in other Pinus species (Calvo et al. 2008; Maia et al. 2012). Six months later (i.e. after the dry season), the seedling density had decreased by $56 \%$. Similar or even greater decreases in seedling density following the dry season have been observed in other species of Pinus (e.g. LuisCalabuig et al. 2002 reported a reduction of $71 \%$ in $P$. pinaster). Seedling emergence was very irregular in the different sectors. Highest values were observed in both sectors closest to the summit and the lowest in the lower sectors on the hillside. At establishment, the planting framework was the same across the whole plantation; however, over the subsequent 17 -year period, the density, height and DBH of individual specimens of $P$. radiata and the cover by the arboreal canopy have decreased with height. The greater penetration of light to the level of the soil and the low litter cover explain the greater success of seedling emergence (Marcos et al. 1994) in sectors I and the II (hill top) than in sectors III and IV (downhill). Moreover, the fire scarcely damaged the pines in sector IV, which preserved most of their needles.

\section{Conclusions}

The Monte Lúa fire provoked a SOM loss of around $15 \%$. The maximum temperature reached at the soil surface was estimated from the comparison between DSC curves of laboratory soil heating at different temperatures and the corresponding burnt soil obtained that is in the interval 150 $200{ }^{\circ} \mathrm{C}$. Thus, taking into account that this temperature interval is lower than ignition temperature of unburnt soil $\left(246^{\circ} \mathrm{C}\right)$, it can be assumed that Monte Lúa fire is a low severity fire.

Germination percentage in the inland provenance was higher than in the littoral provenance for all the fire treatments. Control germination percentage in both provenances was high, and fire treatments with lower intensity associated to the burnt soil do not modify it or do disable it. Nevertheless, germination was totally inhibited at $150-200{ }^{\circ} \mathrm{C}$ treatments.

These results agree reasonably with the scarce post-fire seedling emergence observed in the burnt area, where no viable seeds in soil could persist after the fire and the canopy temperatures could not be high enough to liberate the total aerial seed bank, although some of them might be liberated or even might be transported by the wind from other populations.

Acknowledgements The authors are grateful to D. Arán, R. Álvarez and A. Muñoz for help with the fieldwork and to editors and anonymous reviewers for their valuable suggestions. Some data of this study correspond to the final year project carried out by M. del Valle. The study formed part of projects PIEGAL (10MDS200007PR) and LISVAPES (EM2013/031) financed by the Government of Galicia and the project GESFIRE (AGL2013-48189-C2-R) financed by the Minister of Economy and Competitiveness, Government of Spain.

\section{References}

Calvo L, Santalla S, Valbuena L, Marcos E, Tárrega R, Luis-Calabuig E (2008) Post-fire natural regeneration of a Pinus pinaster forest in NW Spain. Plant Ecol 197:81-90

De la Rosa JM, González-Pérez JA, González-Vázquez R, Knicker H, López-Capel E, Manning DAC, González-Vila FJ (2008) Use of pyrolysis/GC-MS combined with thermal analysis to monitor $\mathrm{C}$ and $\mathrm{N}$ changes in soil organic matter from a Mediterranean fire affected forest. Catena 74:296-303

De las Heras J, Bonilla M, Matínez LW (2006) Germination after heat treatments of Pinus tropicalis Morelet and Pinus caribaea Morelet var. caribaea seeds of west Cuban forests. Ann For Sci 63:469-475

Dell'Abate MT, Benedetti A, Brookes PC (2003) Hyphenated techniques of thermal analysis for characterisation of soil humic substances. J Separation Sci 26:433-440

Díaz-Fierros F, Benito E, Vega J, Castelao A, Soto B, Pérez R, Taboada T (1990). Solute loss and soil erosion in burnt soil from Galicia (NW Spain). In: Fire in Ecosystem Dynamics 1:103-116 
Escudero A, Sanz MV, Pita JM, Pérez-García F (1999) Probability of germination after heat treatment of native Spanish pines. Ann For Sci 56:511-520

EUROSTAT (2011) Forestry in the EU and in the world. A statistical portrait. Office of the European Union. Luxembourg. 107 pp

Fernández JM, Plante AF, Leifeld J, Rasmussen C (2011) Methodological considerations for using thermal analysis in the characterization of soil organic matter. J Thermal Anal Cal 104:389-398

Keeley JE (1994) Seed germination patterns in fire prone Mediterraneanclimate regions. In: Arroyo MTK, Zedler PH, Fox MD (eds) Ecology and biogeography of Mediterranean ecosystems in Chile. California and Australia. Springer Verlag, New York, pp 239-273

Keeley JE, Fotheringham CJ (1998) Smoke-induced seed germination in California chaparral. Ecology 79:2320-2336

Luis-Calabuig E, Torres O, Valbuena L, Calvo L, Marcos E (2002) Impact of large fires on a community of Pinus pinaster. In: Trabaud L, Prodon R (eds) Fire and biological processes. Backhuys Publishers, Leiden, pp 1-12

Maia P, Pausas JG, Vasques A, Keizer JJ (2012) Fire severity as a key factor in post-fire regeneration. of Pinus pinaster (Ait.) in Central Portugal. Ann For Sci 69:489-498

Marcos E, Valbuena L, Luis-Calabuig E, Tárrega R (1994) First stages of post-fire regeneration in Pinus radiata plantations. In: Viegas D (ed) 2nd International conference on forest fire. University of Coimbra, Coimbra, pp 969-978

Marcos E, Tárrega R, Luis E (2007) Changes in a Humic Cambisol heated $\left(100-500{ }^{\circ} \mathrm{C}\right)$ under laboratory conditions: the significance of heating time. Geoderma 138:237-243

Mendes-Lopes JMC, Ventura JMP, Amaral MP (2003) Flame characteristics, temperature-time curves, and rate of spread in fires propagating in a bed of Pinus pinaster needles. Int J Wildland Fire 12:67-84

Moles AT, Drake DR (1999) Potential contributions of the seed rain and seed bank to regeneration of native forest under plantation pine in New Zealand. N Z J Bot 37:83-93

Mollashahi M, Hosseini SM (2007) The effects of storage during 17 years on germination of Pinus radiata from three different sites. For Sci 3:21-30

Pausas JG, Ouadah N, Ferran A, Gimeno T, Vallejo R (2003) Fire severity and seedling establishment in Pinus halepensis woodlands, eastern Iberian Peninsula. Plant Ecol 169:205-213

Pérez-Cruzado C, Sande B, Omil B, Rovira P, Martin-Pastor M, Barros N, Salgado J, Merino A (2014) Organic matter properties in soils afforested with Pinus radiata. Plant Soil 374:381-398

Plante AF, Fernández JM, Leifeld J (2009) Application of thermal analysis techniques in soil science. Geoderma 153:1-10

Raunkiær CC (1934) The life forms of plants and statistical plant geography. Oxford University Press

Reyes O, Casal M (1995) Germination behaviour of three species of the genus Pinus in relation to high temperatures suffered during forest fires. Ann For Sci 52:385-392
Reyes O, Casal M (1998) Germination of Pinus pinaster. P radiata and Eucalyptus globulus in relation to the amount of ash produced in forest fires. Ann For Sci 55:837-845

Reyes O, Casal M (2002a) Experimental field emergence and early survival of six tree species in relation to forest fires. In: Trabaud L, Prodon R (eds) Fire and biological processes. Backhuys Publishers, Leiden, pp 277-290

Reyes O, Casal M (2002b) Effect of high temperatures on cone opening and on the release and viability of Pinus pinaster and $P$. radiata seeds in NW Spain. Ann For Sci 59:327-334

Reyes O, Casal M (2006) Can smoke affect the germination of Pinus syvestris, $P$. nigra, $P$. uncinata and $P$. pinaster? For Ecol Manag 234: 184. doi:10.1016/j.foreco.2006.303

Reyes O, Trabaud L (2009) Germination behaviour of 14 Mediterranean species in relation to fire factors: smoke and heat. Plant Ecol 202: $113-121$

Rovira P, Kurz-Besson C, Coûteaux MM, Vallejo R (2008) Changes in litter properties during decomposition: a study by differential thermogravimetry and scanning calorimetry. Soil Biol Biochem 40:172-185

Ryan KC, Noste NV (1985) Evaluating prescribed fires. En: Lotan JE, Kilgore BM, Fischer WC, Mutch RW (Eds.), Proceedings, Symposium and Workshop on Wilderness Fire, 15-18 November 1983, Missoula, MT. USDA Forest Service, Intermountain Forest and Range Experiment Station, General Technical Report INT-182, Missoula, MT, pp. 230-238.

Salgado J, González MI, Armada J, Paz Andrade MI, Carballas M, Carballas T (1995) Loss of organic matter in Atlantic forest soils due to wildfires. Calculation of the ignition temperature. Thermochim Acta 259:165-175

Salgado J, Mato MM, Vázquez-Galiñanes A, Paz-Andrade MI, Carballas $\mathrm{T}$ (2004) Comparison of two calorimetric methods to determine the loss of organic matter in Galician soils (NW Spain) due to forest wildfires. Thermochim Acta 410:141-148

Trabaud L (1987) Fire and survival traits of plants. In: Trabaud L (ed) The role of fire in ecological systems. SPB Academic Publishing, The Hague

Underwood AJ (1997) Ecological experiments: their logical design and interpretation using analysis of variance. Cambridge University Press, Cambridge, 504pp

Vega JA, Fernandez C, Pérez-Gorostiaga P, Fonturbel T (2008) The influence of fire severity, serotiny, and post-fire management on Pinus pinaster Ait. recruitment in three burnt areas in Galicia (NW Spain). For Ecol Manag 256:1596-1603

Verdes PV, Salgado J (2011) Changes induced in the thermal properties of Galizian soils by the heating in laboratory conditions. J Thermal Anal Cal 104:177-186

Verkaik I, Espelta JM (2006) Post-fire regeneration thinning, cone production, serotiny and regeneration age in Pinus halepensis. For Ecol Manag 231:155-163 